\title{
Study on the Comparative Profits of Different Types of Rural Labor Force
}

\author{
Yang li Yong ${ }^{a}$, Liu De Jiang ${ }^{b}$, Yang Yan Jun ${ }^{c}$ \\ College of Geography and Land Engineering, Yuxi Normal University, Yuxi, Yunnan Province, \\ China \\ ayangliyong@yxnu.net, 'liudejiang@yxnu.net, cyangyanjun@yxnu.net
}

Keywords: Rural Labor Force, Farming, Non-Farming Employment, Comparative Profit

\begin{abstract}
Non-farming employment and transfer of rural labor force are of great significance for solving the problems of agriculture, rural areas and farmers and realizing urbanization. Based on the micro perspective of labor force, this paper empirically analyzes the income differences of different types of rural labor force through the questionnaire of farmers and the method of hypothesis testing. The research shows that farming is significantly lower than non-farming both in terms of labor efficiency and labor income. Although the income gap between farming and non-farming can be narrowed appropriately by expanding the business scale, it is still significantly lower than non-farming income. The higher the degree of non-farming, the greater the efficiency and benefits of non-farming labor. However, when the labor force changes from the main farming to the main non - farming, it will bring the dual reduction of agricultural efficiency and income. The efficiency and benefits of "doing business" are significantly higher than that of "going out to work". It is suggested to increase the efficiency and income of rural labor transferring to non-agricultural industries by expanding the scale and degree of farmland transferring, strengthening labor skills training and supporting farmers returning home to start their own businesses.
\end{abstract}

\section{Introduction}

The agricultural comparative profit is a fundamental issue in the field of agriculture [1]. Some scholars believe that the comparative profit of agriculture is relatively low and it has become a fundamental factor restricting the transfer of agricultural land. The comparative profit of China's grain production is still relatively low, but it is not always declining within agriculture [2]. However, it is biased to think that the agricultural comparative profit is very low. The fundamental reason why there is a binary paradox between the high agricultural comparative profit and the low farmers' income is that the agricultural land operation is too small and the underemployment [1]. The policy support of the government, especially the fund subsidy to farmers, the strength of property rights of farmers to farmland, the average education years and the number of farmers of a farm household, has a significant positive effect on farmers' agricultural income, and has a significant negative effect on the non-farming employment wage income of farmers and their agricultural income [3]. Moreover, farmers with non-farming working experience have higher income than farmers without such experience, and this gap is more prominent at the high end of the income distribution [4]. The lack of alternative income channels for rural residents is a key reason for rural residents to choose farming [5]. Thus, it can be seen that the academic circle has done some beneficial research on agricultural comparative profit, but most of the relevant studies lack empirical evidence of farmers' micro data. In view of this, based on the micro perspective of labor force, this study empirically analyzes the income differences of different types of rural labor force based on the data of household questionnaire survey, so as to provide a decision basis for promoting the rational allocation of rural labor resources. 


\section{Data sources and research methods}

\subsection{Data sources and methods}

Research group with Yunnan province as the research area, using stratified sampling method, chooses a major-grain producing county as a typical county respectively in the northwest, northeast, southeast, southwest and central area of Yunnan province. Then, each county chooses one of the nearest and outer suburbs as a typical village, farmers of which are randomly selected from villager's residence or field to conduct a questionnaire survey. The questionnaire includes information of household members, farmland utilization status, farming and turnover intention and farmland protection cognition. The survey adopts the semi-structured interview mode of participatory rural survey evaluation method [6] to conduct "one-to-one" interviews with farmers, and each household takes about one hour. A total of 525 valid questionnaires were obtained, including 512 farming households and 13 non-farming households.

\subsection{Index selection and description}

The labor input selects the index of "man-day", which is equal to the standard man-day of labor input after converting to eight hours of work per day in that year, divided into non-farming man-day and farming man-day. What needs to be explained is that the number of working days provided by peasant family members will affect the farming and non-farming decision-making of peasant family to a certain extent. Therefore, in order to avoid the interference of the analysis result from special labor (college students, housewives, the severely disabled, sick old man, etc.) who has less man-day and more accurately conduct the comparison of income difference of different types labor, this study according to the labor man-days (including non-agricultural and farming), regardless of age, occupation, etc., uniformly divides labor into effective labor (50 man-days or higher) and invalid labor (<50man-days) two kinds. Except special explanation, this article uses effective labor force to carry on the analysis. Based on the consideration of labor employment decision, this study measures and compares labor income (absolute index) and labor efficiency (relative index).

The labor income chooses the index of "labor net income", which is equal to the net income after deducting the expenditure in that year, including farming labor net income and non-farming labor net income. Among them, the net income of farming and the share of cultivated land area of each family member are converted according to the proportion of farming work days of this member in the family. The "average daily earnings" index is selected for labor efficiency, which is equal to the labor net income divided by the work days, including farming average daily earnings and non-farming average earnings.

\subsection{Mathematical statistics methods}

SPSS 23.0 was used for mathematical statistical analysis of the sample data. Whether the difference is significant, it shall be verified by the hypothesis test method: the significance test of the difference between two independent samples shall be performed using the two independent samples t-test; for the significance test of the difference between two paired samples, the paired samples t-test was used. For the significance test of the difference between multiple sample groups, one-way ANOVA was used, LSD was used for multiple comparisons with homogeneous variance, and Tamhane's T2 was used for multiple comparisons with non-homogeneous variance.

\section{Result and analysis}

\subsection{Types of effective labor and primary occupations}

According to the statistics of the household members interviewed, table 1 shows that among all family members, the invalid labor force accounts for $35.0 \%$ and the effective labor force accounts for $65.0 \%$. In order to further compare the differences of different types of effective labor force, this study divided the effective labor force into four categories: pure non-farming labor force, main non-farming labor force (non-farming man-day is greater than or equal to farming man-day), main farming labor force (non-farming man-day is less than farming man-day) and pure farming labor 
force based on the relative days of non-farming and farming man-day. From the perspective of the type of labor force, the effective labor force is mainly pure farming and main non-farming labor force, accounting for $36.6 \%$ and $31.3 \%$ of the effective labor force, respectively. It can be seen that most of the effective labor force has been transferred to non-farming industries, mainly to part-time but the part-time business is mainly dominated by main non-farming labor force. From the perspective of major occupations, the effective labor force of households mainly consists of "migrant workers" and "household farmers", accounting for $46.4 \%$ and $43.6 \%$ of the effective labor force respectively, while the percentage of those engaged in "business" is only $4.9 \%$. It can be seen that migrant workers are still the main way out for the transfer of rural labor force, while only a small number of workers choose to do business and start a business.

Table1. Types of effective labor and primary occupations

\begin{tabular}{ccccccc}
\hline Types of labor & Quantity & Ratio(\%) & $\begin{array}{c}\text { Primary } \\
\text { occupations }\end{array}$ & Quantity & Ratio(\%) \\
\hline & $\begin{array}{c}\text { Pure } \\
\text { non-farming }\end{array}$ & 369 & 22.6 & $\begin{array}{c}\text { Farming at } \\
\text { home }\end{array}$ & 710 & 43.6 \\
\hline $\begin{array}{c}\text { Main } \\
\text { non-farming }\end{array}$ & 511 & 31.3 & $\begin{array}{c}\text { Going out as } \\
\text { migrant } \\
\text { worker }\end{array}$ & 756 & 46.4 \\
\cline { 2 - 7 } labor & $\begin{array}{c}\text { Main } \\
\text { farming }\end{array}$ & 153 & 9.4 & $\begin{array}{c}\text { Going into } \\
\text { business }\end{array}$ & 80 & 4.9 \\
\cline { 2 - 7 } & $\begin{array}{c}\text { Pure } \\
\text { farming }\end{array}$ & 597 & 36.6 & Administration & 40 & 2.4 \\
\cline { 2 - 7 } & Subtotal & 1630 & 65.0 & Other & 44 & 2.7 \\
\hline Ineffective labor & 876 & 35.0 & Total & 1630 & 100.0 \\
\hline
\end{tabular}

\subsection{Farming man-day of effective labor force}

From the perspective of farming man-days, as shown in figure 1 , more than half $(57.7 \%)$ of effective labor force is engaged in farming with less than 100 man-days. In contrast, only $13.1 \%$ of effective labor force is engaged in farming with more than 250 man-days. This indicates that most of the effective labor force has a large surplus of man-days. It is not difficult to find the internal logic of the transfer of rural labor force: due to less contracted land, less demand for farmland to be shared by labor force, the effective labor force is forced to transfer to non-agricultural industries to find a way out, so as to make full use of their remaining man-days and obtain higher labor benefits.

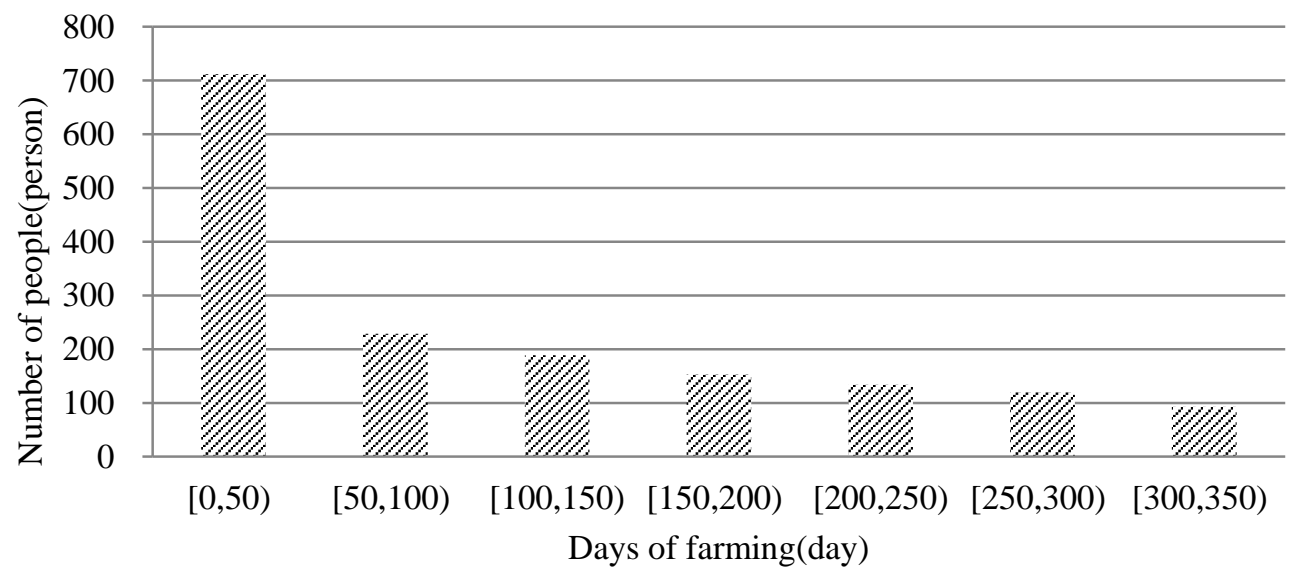

Fig 1. Farming man-day of effective labor force

\subsection{The profit differences of different types of effective labor}

\subsubsection{The profit difference between farming labor and non-farming labor}

For the effective labor force that is only employed in non-agricultural or agricultural work, table 2 shows that the man-day, labor income and average daily income of the pure farming labor force are lower than that of the pure non-farming labor force, and there is a big difference between the farming labor force and the non-farming labor force. According to the two independent samples t-test, the significance p values were all equal to 0.000 , and the significance level of difference was 
1\%. This shows that there are indeed significant differences between pure farming and pure non-farming labor force in terms of man-day, labor income and daily average income: pure farming $<<$ pure non-farming. But there may be a reason for the differing qualities of the workforce. Therefore, further paired samples t-test was conducted for part-time farmers who were both employed in farming and non-farming sectors. The results showed that the man-day, net income and average daily income of farming labor were significantly lower than that of non-farming labor (p $<1 \%$ ) for part-time workers. This further proves that the employment choice between non-farming and farming is one of the main reasons for the difference in labor income, and the comparative profit of farming is significantly lower than that of non-farming. Thus, it can be seen, no matter labor efficiency or labor income, farming is apparently lower than non-farming, which means that if farmers transfer their work from farming to non-farming employment, they can obtain the dual enhancement effect of labor efficiency and labor income. Hence, comparative profits is one of the driving forces for the rural labor force to change from pure farming to part-time work and even pure non-farming labor force.

Table 2. The difference of effective labor force between farming and non-farming

\begin{tabular}{ccccc}
\hline \multicolumn{2}{c}{ Comparison object } & Man-day & $\begin{array}{c}\text { Average daily income } \\
\text { (yuan/man-day) }\end{array}$ & $\begin{array}{c}\text { Net labor income (ten } \\
\text { thousand yuan) }\end{array}$ \\
\hline \multirow{2}{*}{$\begin{array}{c}\text { Single } \\
\text { employed } \\
\text { farmers }\end{array}$} & $\begin{array}{c}\text { Pure } \\
\text { non-farming }\end{array}$ & $288 \pm 55$ & $105 \pm 47$ & $3.0 \pm 1.5$ \\
\cline { 2 - 5 } & Pure farming & $184 \pm 89$ & $35 \pm 19$ & $0.6 \pm 0.4$ \\
\hline \multirow{2}{*}{$\begin{array}{c}\text { Part-time } \\
\text { household }\end{array}$} & Non-farming & $190 \pm 88$ & 0.000 & 0.000 \\
\cline { 2 - 5 } & Farming & $77 \pm 75$ & $84 \pm 34$ & $1.6 \pm 1.1$ \\
\cline { 2 - 5 } & $\mathrm{p}$ & 0.000 & $37 \pm 21$ & $0.3 \pm 0.4$ \\
\hline
\end{tabular}

3.3.2 The difference between farming income of pure farming labor and non-farming income of pure non-farming labor with the same operating scale

In order to further compare the differences between the pure farming labor force of different operating scales, this study divided the pure farming labor force into two categories: small pure farmers $(<4 \mathrm{mu})$ and large pure farmers $(\geq 4 \mathrm{mu})$, and then conducted the single-factor variance analysis together with the pure non-farming labor force. The results of variance analysis in table 3 show that there are significant differences in man-days, labor net income and average daily income between small pure farmers, large pure farmers and pure non-farmers: small pure farmers $<<$ big pure farmers $<<$ pure non-farmers $(\mathrm{p}<1 \%)$. This proves again that no matter labor efficiency or labor income, farming is far less than non-farming. Although it is possible to properly narrow the earnings gap with non-farming sector by expanding the business scale, it is still significantly lower than non-farming sector. It should be noted that the average daily income of small pure farmers is lower than that of large pure farmers. According to the further investigation, due to the shortage of arable resources, small pure farmers have relatively surplus man-days, which makes them input their labor inefficiently on the limited cultivated land, thus making the average daily labor income at a relatively low level which is lower than that of large pure farmers. However, large pure farmers share more farmland than small pure farmers, so they need to provide more man-days, and gain relatively higher agricultural benefits under the dual effect of labor man-day and labor efficiency.

3.3.3 The difference of farming income in different degrees of non-farming labor force

In order to compare the differences of farming income between different degrees of non-farming labor force, this study conducted single-factor variance analysis and test on the agricultural man-day, average daily income and agricultural net income of main non-farming labor force, main farming labor force and pure farming labor force. From table 3, it can be seen that for farming man-days, the differences are as follows: main non-farming $<<$ pure farming $<$ main farming, that is, there are significant differences between main non-farming and main and pure farming, while the differences between main farming and pure farming do not reach the level of $5 \%$ significance. What is worth mentioning is that the man-days of pure farming are less than those of main farming. The main 
reason is that the proportion of effective labor force in the pure farming is higher than that in the main farming, who is less than 60 years old and has relative less agricultural man-day. For the agricultural net income, the difference among main non-farming, main farming and pure farming reaches a significant level of 5\%: main non-farming $<<$ pure farming $<<$ main farming. For the average daily earnings of farming, there was no significant difference (AVOVA significant $\mathrm{p}$ $=0.116>5 \%$ ) among main non-farming, main farming and pure farming, but only slight difference: pure farming < non-farming < main farming. Thus, it can be seen that there is no significant difference in agricultural labor efficiency among different degrees of non-farming labor, and the main reason for the significant difference in farming labor income is agricultural man-days but not agricultural efficiency. When the labor force is further transferred from the main farming to the main non-farming, it will bring the dual reduction of agricultural efficiency and income.

Table 3. Labor differences of different types of effective labor force

\begin{tabular}{|c|c|c|c|c|}
\hline \multicolumn{2}{|c|}{ Comparison object } & Man-day & $\begin{array}{l}\text { Average daily income } \\
\text { (yuan/man-day) }\end{array}$ & $\begin{array}{l}\text { Net labor income (ten } \\
\text { thousand yuan) }\end{array}$ \\
\hline \multirow{3}{*}{$\begin{array}{l}\text { The difference } \\
\text { between pure farming } \\
\text { and pure non - } \\
\text { farming labor force in } \\
\text { different operating } \\
\text { scale }\end{array}$} & $\begin{array}{c}\text { Pure } \\
\text { non-farming }\end{array}$ & $288 \pm 56$ A & $105 \pm 47 \mathrm{~A}$ & $3.0 \pm 1.5 \mathrm{~A}$ \\
\hline & $\begin{array}{c}\text { large pure } \\
\text { farmers }\end{array}$ & $211 \pm 80$ B & $45 \pm 20 \mathrm{~B}$ & $0.9 \pm 0.6 \mathrm{~B}$ \\
\hline & $\begin{array}{l}\text { small pure } \\
\text { farmers }\end{array}$ & $176 \pm 90 \mathrm{C}$ & $32 \pm 17 \mathrm{C}$ & $0.5 \pm 0.4 \mathrm{C}$ \\
\hline \multirow{3}{*}{$\begin{array}{l}\text { The difference of } \\
\text { farming in different } \\
\text { degrees of } \\
\text { non-farming labor } \\
\text { force }\end{array}$} & $\begin{array}{c}\text { Main } \\
\text { non-farming }\end{array}$ & $42 \pm 35 \mathrm{~A}$ & $36 \pm 21 \mathrm{~A}$ & $0.2 \pm 0.2 \mathrm{~A}$ \\
\hline & $\begin{array}{c}\text { Main } \\
\text { farming }\end{array}$ & $191 \pm 60 \mathrm{~B}$ & $38 \pm 21 \mathrm{~A}$ & $0.8 \pm 0.5 \mathrm{~B}$ \\
\hline & $\begin{array}{c}\text { Pure } \\
\text { farming }\end{array}$ & $184 \pm 89$ B & $35 \pm 19$ A & $0.6 \pm 0.4 \mathrm{C}$ \\
\hline \multirow{3}{*}{$\begin{array}{l}\text { The difference of } \\
\text { non-farming in } \\
\text { different degrees of } \\
\text { non-farming labor } \\
\text { force }\end{array}$} & $\begin{array}{c}\text { Pure } \\
\text { non-farming }\end{array}$ & $288 \pm 56$ A & $105 \pm 47 \mathrm{~A}$ & $3.0 \pm 1.5 \mathrm{~A}$ \\
\hline & $\begin{array}{c}\text { Main } \\
\text { non-farming }\end{array}$ & $223 \pm 70 \mathrm{~B}$ & $87 \pm 37$ B & $2.0 \pm 1.1 \mathrm{~B}$ \\
\hline & $\begin{array}{c}\text { Main } \\
\text { farming }\end{array}$ & $80 \pm 38 \mathrm{C}$ & $76 \pm 20 \mathrm{C}$ & $0.6 \pm 0.4 \mathrm{C}$ \\
\hline \multirow{3}{*}{$\begin{array}{l}\text { The difference of } \\
\text { non-farming in } \\
\text { different non-farming } \\
\text { industries }\end{array}$} & $\begin{array}{c}\text { Doing } \\
\text { Business }\end{array}$ & $292 \pm 58$ A & $146 \pm 65 \mathrm{~A}$ & $4.3 \pm 2.2 \mathrm{~A}$ \\
\hline & Fixed work & $280 \pm 70 \mathrm{~A}$ & $114 \pm 46 \mathrm{~B}$ & $3.2 \pm 1.3 \mathrm{~B}$ \\
\hline & Worker & $241 \pm 73$ B & $88 \pm 35 \mathrm{C}$ & $2.1 \pm 1.0 \mathrm{C}$ \\
\hline
\end{tabular}

Note: Different capital letters in the same column indicate that the difference between the two is significant at the $5 \%$ level.

\subsubsection{The difference of non-farming income in different degrees of non-farming labor force}

In order to compare the differences in non-farming income of labor force with different degrees of non-farming, this study tested the significance of differences in non-agricultural man-days, net income and average daily earnings of pure non-farming, main non-farming and main farming labor force through the single-factor variance analysis. From table 3, it can be seen that there are significant differences between pure non-farming, main non-farming and main farming labor force in the three aspects of non-farming man-day, non-farming net income and non-farming average daily income: pure non-farming $>>$ main non-farming $>>$ main farming $(\mathrm{p}<1 \%)$. Thus, it can be seen that the non-farming man-days, efficiency and earnings of farmers differ significantly in different degrees of non-agriculturization. The higher the degree of non-agriculturization of farmers, the greater the non-agricultural man-days, labor efficiency and labor income. This shows that the transfer of rural labor force from main farming to main non-farming and further into pure non-farming will result in the dual enhancement of non-agricultural efficiency and benefits.

3.3.5 The difference of non-farming income in different non-farming industries of labor force

At the same time, in order to verify the difference between non-farming industries, single-factor variance analysis was conducted by selecting the "migrant workers" labor force with the largest proportion, the "administrative enterprise" labor force with strong stability and the "business" labor force with high risk. It can be seen from table 3 that for non-farming man-days, the difference among the "business", "administrative enterprise" and "migrant workers" labor force reaches $1 \%$ 
significance level, but the difference between the "business" and "administrative enterprise" labor force does not reach 5\% significance level. For non-farming net income and non-farming average daily income, they both perform: business $>>$ administrative enterprise $>>$ migrant work $(\mathrm{p}<1 \%)$. This shows that the non-farming man-day of migrant workers is significantly lower than that of administrative and business workers, which also reflects the uncertainty of the man-day of migrant workers to some extent. The non-agricultural labor efficiency and income of the labor in different non-farming industries are obviously different. Compared with administrative business and migrant work, the peasants can obtain higher labor efficiency and income by doing business.

\section{Conclusions and policy suggestions}

The empirical research of this paper shows that the labor efficiency and labor income of farming employment is significantly lower than that of non-farming employment. Although the income gap between farming and non-farming can be narrowed by appropriately expanding the business scale, it is still significantly lower than non-farming. There is no significant difference in farming labor efficiency between different degrees of non-farming labor, but there is significant difference in farming labor income, which is mainly due to farming man-days rather than farming efficiency. When the labor force is further transferred from the main farming to the main non-farming, it will bring the dual reduction of agricultural efficiency and income. The non-farming man-days, efficiency and income of farmers differ significantly in different degrees of non-agriculturization. The higher the degree of non-agriculturization of farmers, the greater the non-agricultural man-days, labor efficiency and labor income. When the rural labor force is transferred from main farming to main non-farming and further to pure non-farming labor, both non-farming efficiency and benefits will be increased. The non-agricultural labor efficiency and income of the labor force in different non-farming industries are obviously different. For the administrative enterprise and migrant workers, the peasants engaged in business can obtain higher labor efficiency and income, while the migrant workers cannot guarantee their income due to the uncertainty of man-day.

In order to promote the transfer of rural labor to non-farming industries and improve its efficiency and benefits, the rural labor allocation policy recommendations can be focused on the following aspects. First, expand the scale and degree of farmland circulation and promote the breadth and depth of rural labor transfer. Second, strengthen the training of labor skills and improve the vocational ability of the transferred labor force. Third, encourage and support farmers to return to their hometowns to start their own business and promote the local transfer of rural labor.

\section{References}

[1] M. H. Tang and S. A. Huang, Is comparative profit in agriculture low based on the analysis of the two different cost-return-accounting frameworks, Journal of Zhongnan University of Economics and Law, vol. 4, pp. 53-59, 2011.

[2] C. F. Fan and J. M. Shi, Is the comparative benefit of grain production declining? Compared with the data from the investigation on the cost and benefit of planting grain and oil, vegetables and apples, Journal of Agrotechnical Economics, vol. 2, pp. 31-39, 2013.

[3] M. Z. Luo and B. L. Luo, Summary and Analysis of property right intensity, Policy support and Agricultural income, Economic Perspectives, vol. 9, pp. 91-94, 2012.

[4] L. Ran, J. Z. Xie and M. Zhang, Non-agricultural work experience and farmers' income: an empirical study based on quantile regression and decomposition, Journal of Agrotechnical Economics, vol. 6, pp. 32-39, 2013.

[5] Q. S. Xie and R. S. Ma, The Ways of Alternative Income, Family Labor Surplus and Farmers' Choose between "Work in the city" or "Make a Living on the Land, Population \& Economics, vol. 83, pp. 90-96, 2013. 
[6] X. B. Hua, J. Z. Yan, and Q. Wang, Comparative analysis on influencing factors of cultivated land use intensity in valley and middle mountain area of upper Dadu River watershed, Transactions of the Chinese Society of Agricultural Engineering, vol. 20, pp. 234-244, 2013. 